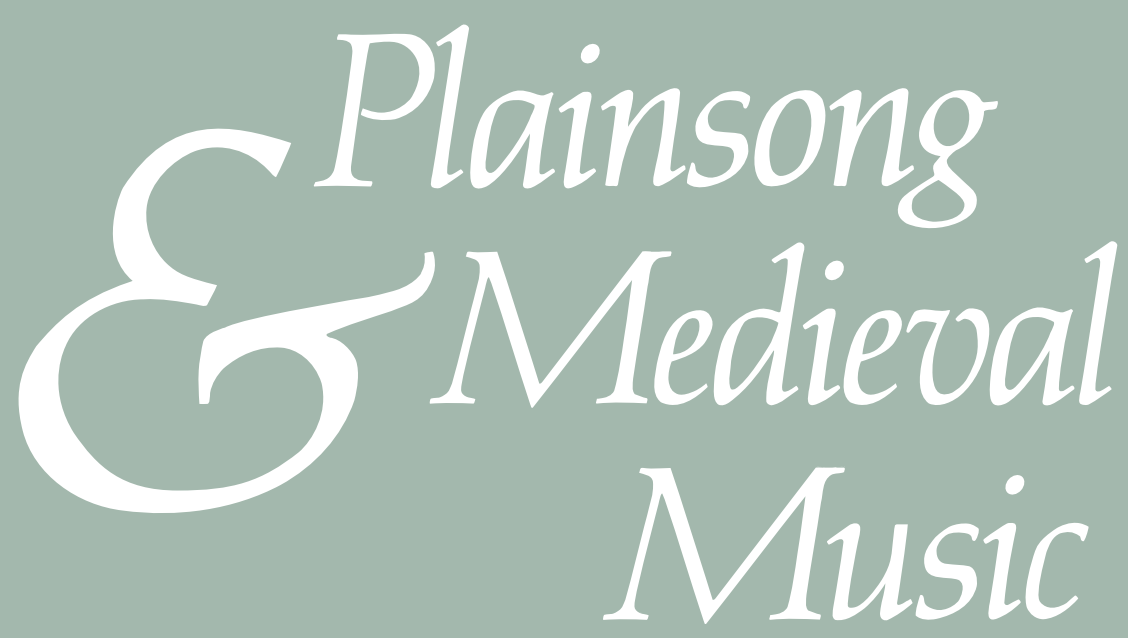

CAMBRIDGE UNIVERSITY PRESS 


\title{
Plainsong and Medieval Music
}

Published in Association with the Plainsong and Medieval Music Society and the International Musicological Society Study Group 'Cantus Planus'

\author{
EDITORIAL COMMITTEE \\ James Borders, University of Michigan (Co-Editor) \\ Christian Leitmeir, Bangor University (Co-Editor) \\ Margaret Bent, All Souls College, Oxford (Consulting Editor) \\ Susan Rankin, University of Cambridge (Consulting Editor) \\ Edward Roesner, New York University (Consulting Editor) \\ Nicolas Bell, The British Library (Review Editor, Books) \\ Günther Michael Paucker, Weinstadt (Chant Bibliography) \\ Jerome F. Weber, Utica, New York (Review Editor, Audio) \\ John Harper, Bangor University (Chair of Committee) \\ Giacomo Baroffio, University of Pavia \\ John Caldwell, University of Oxford \\ Richard Crocker, University of California at Berkeley \\ Helen Deeming, Royal Holloway University \\ Emma Dillon, University of Pennsylvania \\ Joseph Dyer, Massachusetts, USA \\ Manuel Pedro Ferreira, University of Lisbon \\ David Hiley, University of Regensburg \\ Lori Kruckenberg, University of Oregon \\ Elizabeth Eva Leach, University of Oxford \\ Alexander Lingas, City University, London \\ Christopher Page, University of Cambridge \\ Owen Rees, University of Oxford \\ Leo Treitler, Graduate Center of the City University of New York \\ Christian Troelsgård, University of Copenhagen \\ Bruno Turner, Worthing, West Sussex \\ Philippe Vendrix, Centre d'Etudes Supérieures de la Renaissance, Tours \\ Ronald Woodley, University of Central England, Birmingham Conservatoire
}

SUBSCRIPTIONS Plainsong and Medieval Music (ISSN 0961-1371) is published twice a year in April and October. Two parts form a volume. The subscription price (excluding VAT) of volume 21 (2012), which includes print and electronic access, is $£ 112$ net (US\$197 in the USA, Canada and Mexico) for institutions; $£ 32$ net (US\$48 in the USA, Canada and Mexico) for individuals, which includes print only, ordering direct from the publisher and certifying that the journal is for their personal use. The electronic-only price available to institutional subscribers is $£ 102$ (US\$178 in the USA, Canada and Mexico). Single parts are $£ 57$ (US\$97 in the USA, Canada and Mexico) plus postage. EU subscribers (outside the UK) who are not registered for VAT should add VAT at their country's rate. VAT registered subscribers should provide their VAT registration number. Japanese prices for institutions are available from Kinokuniya Company Ltd, P.O. Box 55, Chitose, Tokyo 156, Japan. Prices include delivery by air where appropriate. Members of the Plainsong and Medieval Music Society receive the Journal as part of their membership subscription. Special subscription rates are available to members of Cantus Planus. For details please contact journals@cambridge.org.

Orders, which must be accompanied by payment, may be sent to a bookseller, subscription agent or direct to the publisher: Cambridge University Press, The Edinburgh Building, Shaftesbury Road, Cambridge CB2 8RU, UK; or in the USA, Canada and Mexico: Cambridge University Press, Journals Fulfillment Department, 100 Brook Hill Drive, West Nyack, New York 10994-2133, USA.

COPYING This journal is registered with the Copyright Clearance Center, 222 Rosewood Drive, Danvers, MA 01923, USA. Organisations in the USA who are registered with C.C.C. may therefore copy material (beyond the limits permitted by sections 107 and 108 of U.S. Copyright law) subject to payment to C.C.C. of the per-copy fee of $\$ 30$. This consent does not extend to multiple copying for promotional or commercial purposes. Code 0961-1371/2012.

ISI Tear Sheet Service, 3501 Market Street, Philadelphia, PA 19104, USA, is authorised to supply single copies of separate articles for private use only.

Organisations authorised by the Copyright Licensing Agency may also copy material subject to the usual conditions. For all other use, permission should be sought from Cambridge or from the North American Branch of Cambridge University Press.

This journal is included in the Cambridge Journals Online service which can be found at journals.cambridge.org.

(C) Cambridge University Press 2012 


\section{Plainsong and Medieval Music}

VOLUME 21 NUMBER 1

\section{CONTENTS}

Ambrosian Mass chants before the Carolingian intervention

TERENCE BAILEY

The Latin antiphon and the question of frequency of interpolation

EDWARD NOWACKI

The transmission of the polyphonic Amen in the early fifteenth century

ERIKA HONISCH

\section{Recordings}

Recent recordings of plainchant

JEROME F. WEBER

Review

Gunilla Iversen, Laus angelica: Poetry in the Medieval Mass 


\section{CONTRIBUTORS}

Terence Bailey has taught at three Canadian universities beginning in 1963. He has devoted most of his research since 1980 to the music and liturgy of the Milanese Church, and lately to the question of the relationship between Ambrosian and Gregorian chant repertoires.

Erika Supria Honisch is a Postdoctoral Fellow at the University of Toronto. A recent recipient of the American Musicological Society's Howard Mayer Brown Fellowship (2009), she completed her doctoral work at the University of Chicago (2011) with a dissertation on music and religious culture in Prague during the reign of Rudolf II (1576-1612).

Edward Nowacki is Professor Emeritus at the College-Conservatory of Music, University of Cincinnati. His research has focused on theories of orality as applied to Gregorian chant in Frankish and Old Roman transmission. He is currently writing a volume of essays on ancient Greek and medieval Latin music theory. 